\title{
Polycentric urban development in post-socialist context: the case of the Budapest Metropolitan Region
}

\author{
TÜNDE SZABÓ, BALÁZs SZABÓ and ZoLTÁN KOVÁCS
}

\begin{abstract}
Even though the concept of polycentric urban development has been high on the agenda in the literature it has rarely come to the fore in academic papers dealing with the postsocialist cities. The main aim of this paper is to analyse the evolving polycentric pattern of urban development in the metropolitan region of Budapest. For the purpose of study we use commuting data of the 1990, 2001 and 2011 national census. The rapid transformation of Budapest after 1989 the re-establishment of market mechanisms, the privatisation of housing, the liberalisation of the property market, and the growing re-integration of the city to the world economy affected not only the core city but also the metropolitan periphery. The previously rather homogeneous structure of the metropolitan periphery experienced significant changes in the course of the transformation. The advantages of location, which had been insignificant during the state-socialist period, once again became truly beneficial which resulted in growing disparities in the metropolitan periphery. Since 1990 the functional interplay, cooperation, interdependence as well as physical infrastructural linkages between Budapest and its metropolitan zone have been further intensified. Residential suburbanisation and the suburbanisation of business activities led to new flows of commuting within the metropolitan region. Our findings show that the reallocation of urban functions took place in the wider metropolitan zone of Budapest among existing centres, which fits to the European version of post-suburbanisation concept rather than the US one.
\end{abstract}

Keywords: polycentric city, urban deconcentration, post-socialist urban transformation, Budapest

\section{Introduction}

The concept of polycentric urban development has been increasingly applied both in academic papers and European policy documents. This is closely linked to the fact that the model of monocentric city has given way to more polycentric

\footnotetext{
${ }^{1}$ Institute of Geography, Research Centre for Astronomy and Earth Sciences, Hungarian Academy of Sciences, H-1112 Budapest, Budaörsi út 45.

E-mails: szabo.tunde.sm@gmail.com, szabba@freemail.hu, zkovacs@iif.hu
} 
spatial patterns at the end of the $20^{\text {th }}$ century (CHAmpion, A.G. 2001; Hall, P. 1993, 2009). The reasons for polycentric urban development are multifaceted, they include the changing modes of transportation as well as changes of the mobility behaviour of the labour force, a shift from production of goods to service provision in the advanced economies, but also the changing demographic composition of city-regions (Bontje, M. 2001; Bontje, M. and Kepsu, K. 2013).

Cities of Central and Eastern Europe (CEE) have been affected by multiply transformations since the early 1990s, which reflect mainly global urbanisation trends, modified by regional peculiarities of post-socialist social arrangements (Axenov, K. et al. 2006; Gentile, M. et al. 2012; Ś́KORA, L. 2009). Even though urban sprawl has become one of the dominant urban phenomena in post-socialist Central and Eastern Europe (Brade, I. et al. 2009; Кок, H. and Kovács, Z. 1999; LeEtMAA, K. and Tammaru, T. 2007; OuredničeK, M. 2007; Stanilov, K. and SýKora, L. 2014), the concept of polycentric urban region has rarely come to the fore in academic papers dealing with the region. Among the few examples DövéNYI, Z. and Kovács, $Z$. (2006) analysed the emergence of new economic poles in the metropolitan region of Budapest. In a theme issue Karel MaIER (2009) discussed polycentric development and national spatial development policy in the Czech Republic. In the same vein interpretations of national policy goals and polycentric urban development were put forward for Slovakia (FINKA, M. 2009), Hungary (RAdvánszKi, Á. 2009) and Slovenia (Pichler-Milanović, N. 2014). Yet, very little - if at all - empirical evidences have been provided about the transformation of major metropolitan regions towards a more polycentric pattern in CEE.

The main aim of this paper is to analyse the level of polycentrism in the metropolitan region of Budapest with the aid of statistical data from the 1990, 2001 and 2011 censuses. Based on commuting data of the three consecutive censuses we seek to answer the following questions:

- How has the role of Budapest and its metropolitan region changed in the national labour mobility system?

- How have local job centres in the metropolitan region of Budapest evolved since the collapse of communism, and what are their relationships with each other and the capital city?

- How can the processes around Budapest be fitted into the wider theoretical contexts of polycentric urban development and post-socialist urban transformation?

The rest of the paper is divided into four parts. The next section briefly introduces the most relevant theoretical interpretations of polycentric territorial development. After the theoretical context the methods and data used in our study are described. In the following section we present our research findings regarding the new pattern of journey to work flows within the metropolitan region of Budapest. In the final section we try to fit the observed processes into a wider conceptual framework. 


\section{Theoretical interpretations of polycentric territorial development}

Analysing the scientific literature on polycentricity the theoretical contribution of economic geography and critical urban geography deserve special attention. On the one hand, economic geographers often emphasise that the 'polycentric city' is an imprint of the prevailing conditions of urban development: an urban form fitting to the reigning social system's institutional, political and power arrangements. In the second half of the $20^{\text {th }}$ century the crisis of the Fordist capital accumulation regime with its decreasing returns was replaced by the flexible accumulation of the post-Fordist era (PeEt, R. and HaRtwick, E. 2009).

The transformation of the mode of production based on information production and processing has altered inter-firm and intra-firm relations (HALL, P. and PAIN, K. 2006). The new economic relations were increasingly characterised by changing conditions in the organisation of labour, growing role of subcontracting, specialisation and outsourcing of production to smaller plants, and particularly, by changing spatial scales of the world economy (Anas, A. et al. 1998; Duranton, G. and Puga, D. 2004; Rosenthal, S.S. and Strange, W. 2004; Malmberg, A. 2009). These changes also implied an urban fabric steadily adjusting to the changing mode of production (Logan, J.R. and Swanstrom, T. 2005), which has taken shape in modified land use patterns and urban structure. On the one hand, the postFordist city-region has been increasingly characterised by a growing intra-metropolitan division of labour, and on the other hand, macro-level city relations have become also more hierarchical, dominated by powerful network nodes (see for instance SAssen, S. 2001; Scott, A.J. et al. 2001; MALmberg, A. 2009).

As a second strand of theoretical stream, critical urban studies advocate another interpretation on the changing spatial structure of city regions, by reviving urban political economy (Peet, R. and Hartwick, E. 2009). According to BRENNER, N. and THEOdore, N. (2002) to maintain capital recovery cities should be periodically reconstituted. The capitalist production of space - as a mean to secure capital reproduction - is organised around uneven development and a spatially differentiated devaluation of property (HARVEY, D. 1978). Diffusion and steady re-concentration of capital reflects unequal returns. Increasing yields attract capital to edge cities or even back to the gentrifying city core, waterfront or brownfield sites.

On the contrary, emptying suburban production spaces or traditional downtown retail zones prove to be unattractive and unprofitable (Sмітн, N. 1982; Crilley, D. 1993). Periodical rounds of accumulation and devaluation implies crisis on a certain point, which discards former territorial organisation of capital, and reconstitute a recent use of space on account of a new capital accumulation regime (BRenner, N. and Theodore, N. 2002). Crisis can be partly explained by breakdown of mechanism of uneven development which also means a failure in ordering intra-metropolitan disparities of capital (HARVEY, D. 1978). 
A striking spatial feature of the post-Fordist shift was a pervasive urban de-concentration. Since the 1960s the intra-metropolitan relations of city regions became more diverse and multidirectional (Krugman, P. 2000; Fujita, M. et al. 2000). New types of relations evolved, empowering favourable locations within the wider metropolitan region to embed in production or service provision previously not experienced in that part of the city region. City regions became more dispersed, as former zonal division of urban functions typical for the monocentric city has been loosen. Recent trends of urbanisation are called 'post-suburbanisation' in the English literature, and 'Zwischenstadt' in the German urban studies. Essentially, both terms are applied to embrace socio-spatial processes connected with the transformation of the monocentric city, due to:

- a diversification of peri-urban areas with new urban functions (production or service facilities),

- an increasing intensity and diversity of spatial relations among metropolitan centres, due to new economic activities,

- the development of action fields around peri-urban centres, that enables everyday life without dependence on the core city,

- and an increasing number of residents and jobs in the peri-urban area (Volgmann, K. 2012).

Slight differences between the meanings of post-suburbia and 'Zwischenstadt' point to divergences in urbanisation in Europe and North America. In the latter context post-suburbanisation is a pluralist perception of transforming urban structures underpinned by such theoretical constructs as 'exopolis' (Soja, E.W. 1996), 'edge city' (Garreau, J. 1992), 'metroburbia' (KNox, P. 2008), 'flexspace' (LeHRER, U.A. 1994) all aiming at embracing social and spatial conversion of metropolis regions in the US West coast (PHELPS, N. and $\mathrm{Wu}, \mathrm{F}$. 2011). Conceptual heterogeneity is essential here, as it refers to an evolving disorder of urban functions, forms and land use, toward diverging development trends of the city regions (KeIL, R. and Young, D. 2011). On the contrary, post-suburbanisation in Europe generally means the reallocation of urban functions among existing centres, rather than metropolitan-wide sprawl of residential and economic activity. 'Leap frogging' (i.e. growth beyond the suburban residential belt) remains limited (BONTJE, M. and BURDACK, J. 2011).

Since the new millennium polycentricity has become a central issue in European spatial development and planning (Albrechts, L. 2001; Davoudi, S. 2003; FALUdi, A. 2004). The concept of polycentric city has been increasingly perceived as a policy panacea, which enables political actors to manage contradictory or even explosive situation (i.e. growth versus social equality), pretending political consensus (VANDERMOTTEN, C. et al. 2008). Although critical investigations have not yet verified the social benefits of polycentric city (see for instance BAILEY, N. and TUROK, I. 2001), an econometric-oriented wing of spatial sciences is aspired to prove the economic benefits of polycentric urban 
networks (De Goei, B. et al. 2010; Burger, M. and Mejers, E. 2012). They argue that the diversification of specialised services at various locations within the same urban region enables a powerful metropolitan economy.

In the light of the discussed literature it is timely to put the question if the transformation from state-socialist to capitalist socio-economic order in Central and Eastern Europe has brought about a shift from monocentric to polycentric metropolitan structures. Whether processes of contemporary transformation of urban areas around the world are also present in the postsocialist context. Have relevant EU policies related to the concepts of sustainable, balanced, and polycentric development at the national, regional, and local levels yielded any results in the new member-states? To answer these more general questions we use the metropolitan region of the Hungarian capital, Budapest, as a case study.

\section{Data and methods}

For the sake of analysis employment and commuting data at the level of municipalities in Hungary and in the Budapest Metropolitan Region from the 1990, 2001 and 2011 censuses were used. In order to measure the level of policentricty, first, we divided the metropolitan region of Budapest into three areas on the basis of administrative boundaries and the commuting flows recorded in the 2001 national census (Figure 1):

- Core City (CC) - Budapest proper within the official administrative boundaries;

- Functional Metropolitan Area (FMA) - daily urban system at microregional level characterised by intensive commuting to work in the CC. FMA was delimited at the municipality (NUTS 5) level using the threshold of 25 per-

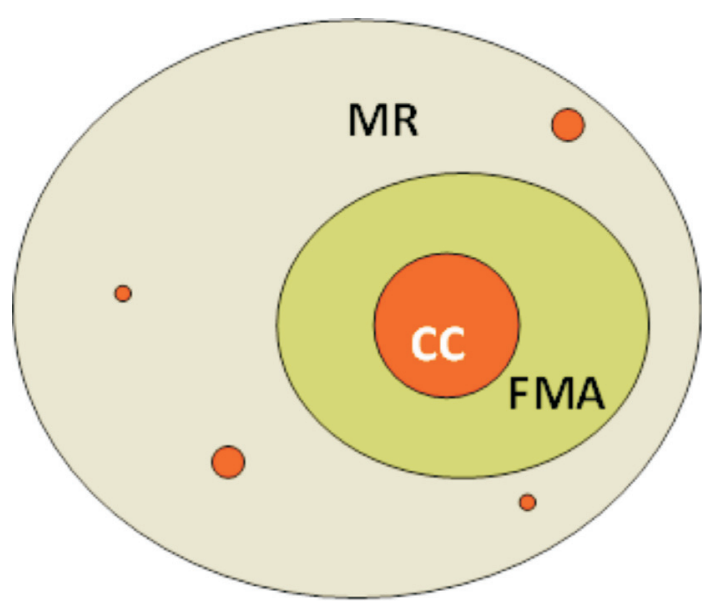
cent of commuters to the core city among the economically active population. In addition the principle of territorial consolidation was applied (excluding

Fig. 1. Subdivision of Budapest Metropolitan Region. $-\mathrm{CC}=$ Core City; FMA = Functional Metropolitan Area; $\mathrm{MR}=$ wider Metropolitan Region. Source: POLYCE 
municipalities that are islands outside the core territory and including those that form windows inside the territory). The total number of municipalities FMA of Budapest is 109, which slightly exceeds the number of municipalities in the officially designated by the Action on the Budapest Agglomeration (80).

- Metropolitan Region (MR) - wider hinterland of the city. MR was delimited at the micro-region (NUTS 4) level using the threshold of 10 percent of commuters to the core city among the economically active population of the centre of micro-region. The total number of municipalities in the MR of Budapest is 284 .

Secondly, as polycentricity is usually measured within a region by the relations between its urban centres, urban centres in the FMA and MR of Budapest had to be identified. This was performed at the municipal (LAU2) level using data on the number of local jobs. A 'job centre' was considered to be a municipality that provide certain amount of employment opportunities for the neighbouring municipalities. Job centres within the FMA were identified using a threshold of 1,000 jobs (i.e. job centres with local influence). Altogether 47 such centres were identified. Within the MR the threshold of 3,000 jobs was applied, which meant job centres with microregional influence. On the basis of the 2001 census 10 such centres were identified. The functional linkages between job centres of the FMA and MR were analysed by commuting-to-work flows provided by the 1990, 2001 and 2011 censuses.

The analysis focused on the reciprocal and hierarchical component of each commuting flow. Reciprocal component is the sum of commuting fluctuation between two centres. Hierarchical component is the remaining unidirectional flow. Thus, in the case of 65 percent reciprocity the relation between two centres was considered 'reciprocal', whereas below 35 percent reciprocity the relation was defined as 'hierarchical'. Relations with reciprocity between 35 and 65 percent were considered as plural relation that maintains certain hierarchical subordination, yet, with significant reciprocity.

\section{Research findings}

\section{Territorial shifts of population and employment}

Since 1990 substantial shifts in the distribution of population has taken place both in Hungary and in the Budapest Metropolitan Region (Table 1). Due to natural decrease and the outflow of population (i.e. suburbanisation) Budapest lost nearly 300,000 inhabitants, and the share of the compact city within the population of the wider metropolitan zone sank from 61.4 to 52.7 percent. At the same time a dynamic population increase has been registered in the Functional Metropolitan Area, i.e. the inner part of the metropolitan zone, which maintains the strongest functional connections with the capital city. 


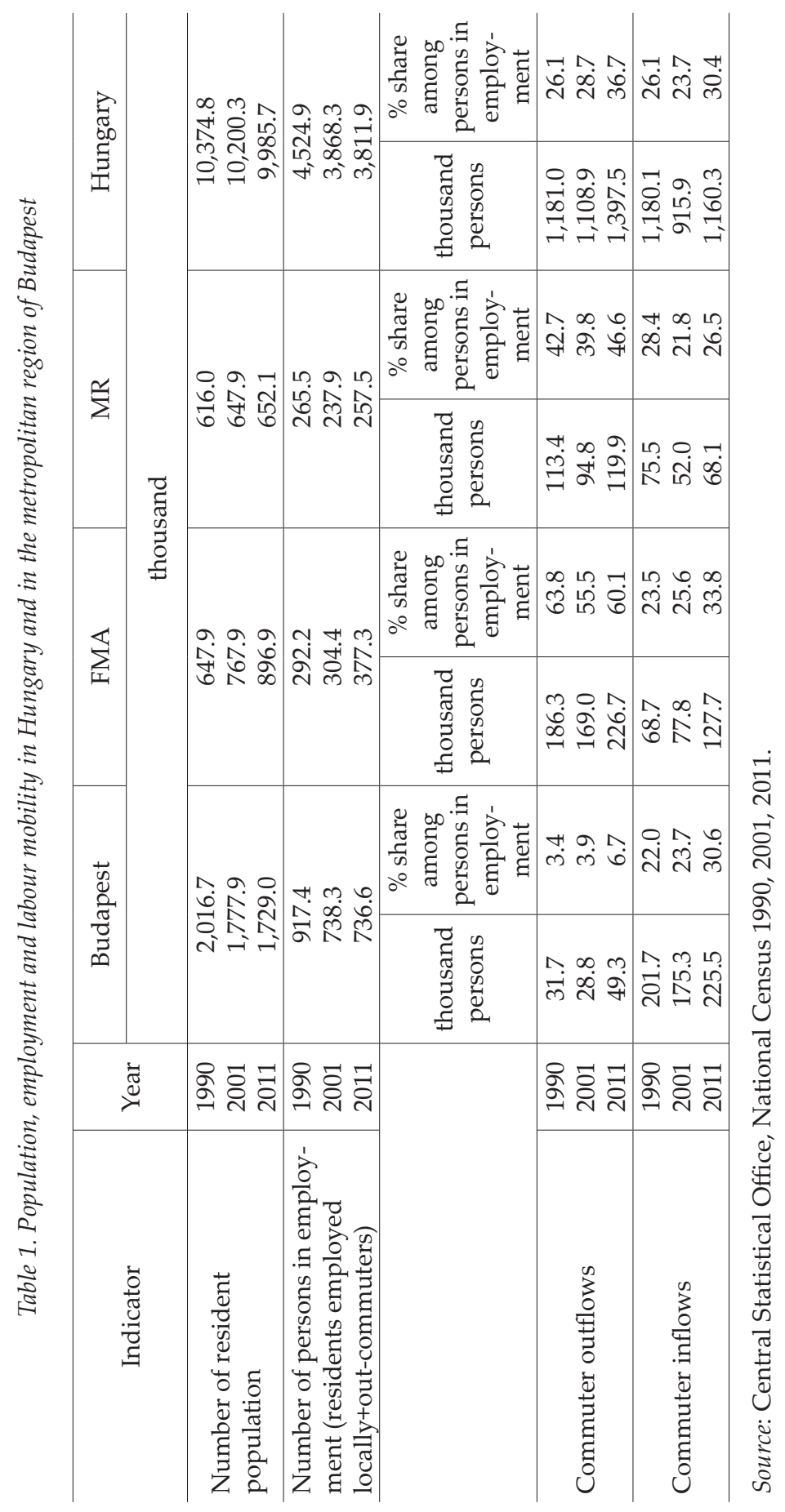


The process of urban sprawl around Budapest and its underpinning factors have been discussed in more details by Kovács, Z. and Tosics, I. (2014). Here we would only like to note that residential suburbanisation in Budapest became more pronounced by the mid-1990s, reaching a net figure of 18,000 residents per year. This trend was gradually reversed, and since 2009 Budapest restarted to have a migration surplus; thus the net population decline in the city was reduced in recent years.

The total population weight of the Budapest Metropolitan Region slightly increased within the country as the population of Hungary decreased by 389,000 while the metropolitan region stagnated at 3.2 million between 1990 and 2011. Intensifying labour relations between Budapest and its hinterland due to suburbanisation, and the growing population weight of the city region together imply that the overall role of Budapest and its metropolitan region within the country's labour mobility flows has increased since 1990.

\section{Changing patterns of labour mobility in Hungary}

As national data show the role of commuting to work has significantly increased in Hungary since 1990. On the eve of the transition 26.1 percent of the workers in employment commuted which rose to 36.7 percent by 2011. The increasing mobility of labour is in line with the post-Fordist transformation of the economy and the concomitant growth of private car ownership. Due to the robust economic transformation traditional commuting destinations like heavy industrial regions and their cities (e.g. Miskolc, Ózd, Tatabánya) lost their significance whereas new types of commuting emerged, like commuting abroad (in 2011 already 83,822 persons), commuting to more than one destination (in 2011 already 153,410 persons), or commuting from bigger cities (e.g. Budapest) to the countryside (i.e. neighbouring suburban localities).

The role of Budapest and its metropolitan region in the national labour mobility system has significantly increased. In 199029.3 percent of all registered commuter inflows were realised in the metropolitan region of Budapest, while in 2011 already 35.5 percent. This change indicates the growing concentration of jobs within Hungary, and the increasing role of Budapest and its closer environment in national labour flows. The growing mobility of local labour in and around Budapest is basically the result of higher income levels and better opportunities for travel to work (e.g. higher density of roads, higher density of public transport) (Table 2).

However, within the metropolitan region a gradual de-concentration of jobs and a new pattern of commuting to work could be observed. On the one hand, the number of persons in employment first sharply decreased in 
Table 2. Spatial differentiation of jobs and workforce in Hungary and in the metropolitan region of Budapest

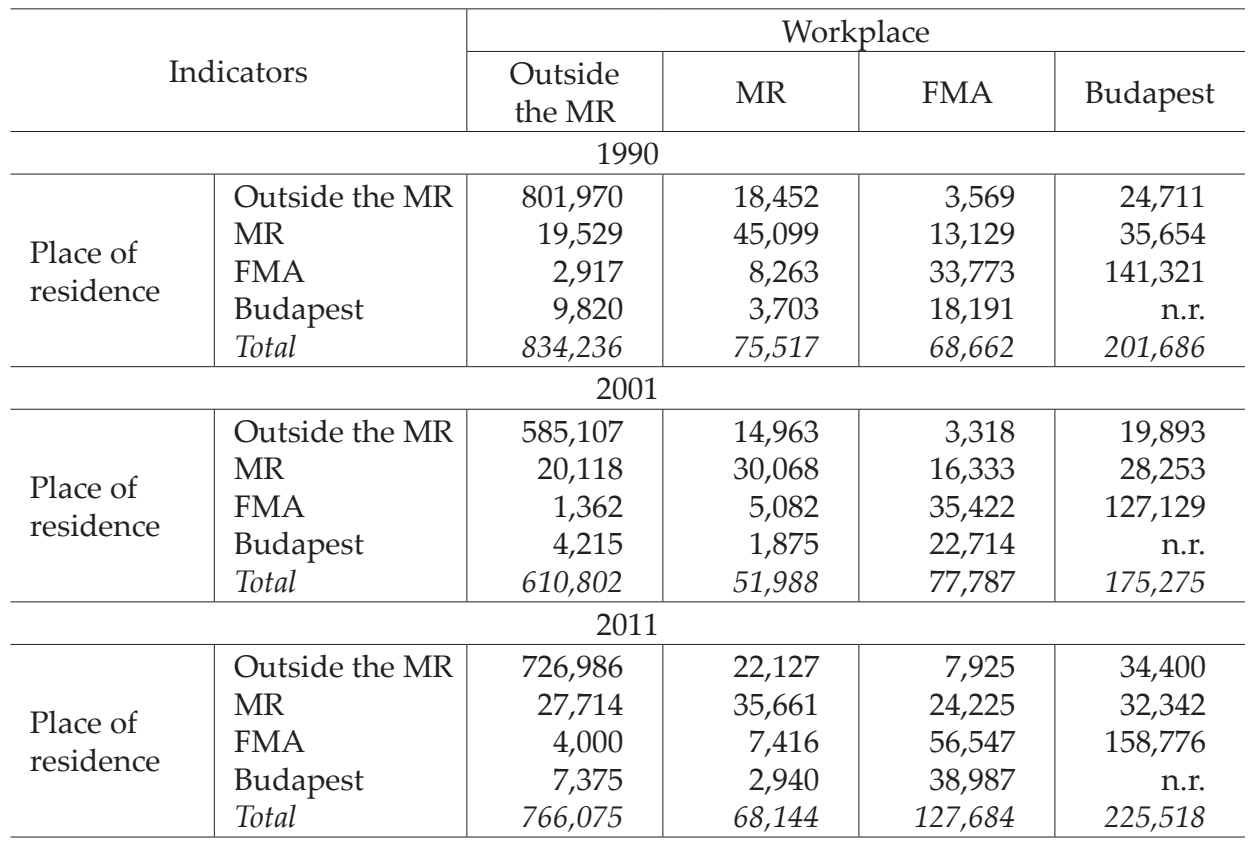

Source: Central Statistical Office, National Census 1990, 2001, 2011. n.r.: not relevant

Budapest, as a consequence of economic restructuring and commencing suburbanisation between 1990 and 2001, which was followed by a stagnation of employed people between 2001 and 2011. On the other hand, the number of employees grew by 30 percent in the FMA in the same period.

The pattern of commuting has also changed. The share of the compact city (Budapest) in journey to work moves was 58.3 percent in 1990 within the metropolitan region, which fell to 53.5 percent by 2011. At the same time the share of the Functional Metropolitan Area (FMA) increased from 19.8 to 30.3 percent. This can be perceived as an outcome of suburbanisation of industry and services after the turn of the century (Kovács, Z. and Tosics, I. 2014). The connection between the FMA and the compact city became intensified with probably more reciprocal flows.

\section{Commuting flows in the metropolitan region}

Budapest is still the primary destination of commuting within the metropolitan region, however, the role of commuting outflows from the capital city has 
strengthened over time. On the eve of the 2011 census already nearly 50, 000 active earners from Budapest were employed outside the city. Most of them were attracted to bigger employment nodes of the FMA like Budaörs (ca. 8,000 people), or Gödöllö (Photo 1). This also means that the role of FMA and to a lesser extent also the outer zone of the MR as targets of commuting has grown.

The number of commuters employed in the FMA and MR increased by 51,000 between 1990 and 2001. Substantial part of them are originating from Budapest, however, in the case of the outer zone of the MR the number of commuters from other parts of Hungary is also significant. Thus, reciprocal commuting flows and journey to work connections among the city, its narrower and wider metropolitan zones have become more intense and complex since 1990.

To test our hypothesis regarding the growing role of reciprocal commuting in the Budapest Metropolitan Region we recorded all connections where both

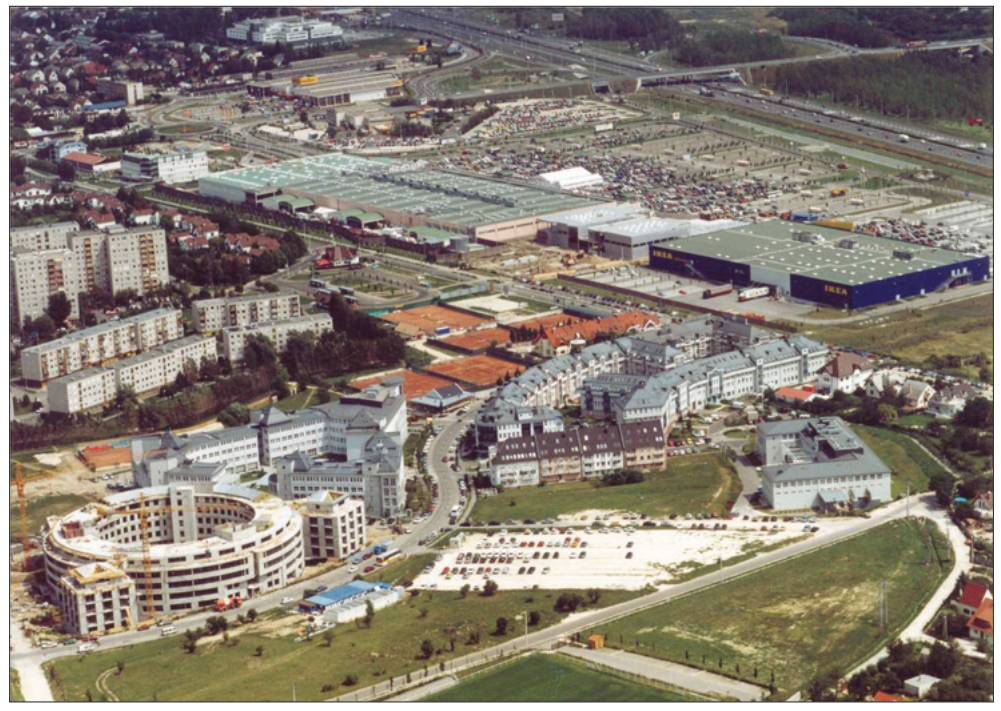

Photo 1. Budaörs edge-city at the western gate of Budapest with multifunctional economy

Table 3. Reciprocal commuting among the municipalities of the Budapest Metropolitan Region

\begin{tabular}{c|c|c|c|c}
\hline \multirow{2}{*}{ Year } & \multicolumn{4}{|c}{ Number of reciprocal connections } \\
\cline { 2 - 5 } & $<35 \%$ & $35-65 \%$ & $>65 \%$ & Total \\
\hline 1990 & 46 & 26 & 14 & 86 \\
2001 & 51 & 19 & 20 & 90 \\
2011 & 47 & 40 & 24 & 111 \\
\hline
\end{tabular}

* Only those connections are considered where the number of inflow and outflow commuters exceeds 200 persons. Source: Central Statistical Office, National Census 1990, 2001, 2011. 
the number of inflow and outflow commuters exceeded 200 persons. In 1990 only 86 such connections were recorded, which grew to 111 by 2011 (Table 3).

As our data show, while the number of 'hierarchical' connections (reciprocity level is below 35 percent) stagnated between 1990 and 2011, the number of reciprocal connections increased from 14 to 24 in the same period.

Even though the role of Budapest in reciprocal connections is still dominant, after 2001 a growing share of them has been realised among subcentres of the FMA (Figure 2). At the same time the share of intermediate reciprocity (i.e. between 35 and $65 \%$ ) has also grown, and spatially became more evenly spread.

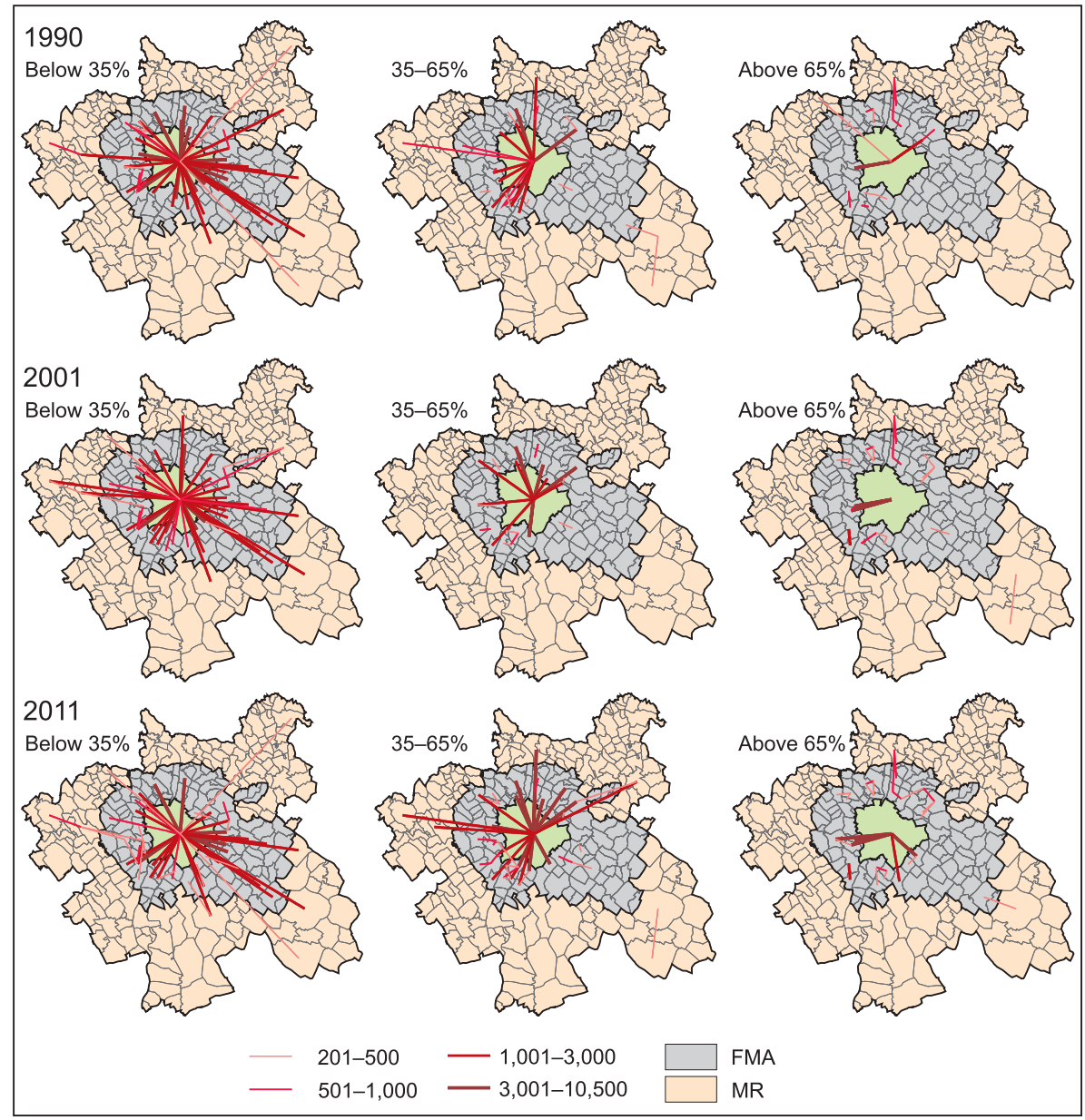

Fig. 2. Reciprocity of commuting in the Budapest Metropolitan Region. Source: Central Statistical Office, National Census 1990, 2001, 2011. 


\section{Discussions and conclusion}

According to urban geographers one of the most important spatial phenomena of post-socialist urban transformation is suburbanisation (BRADE, I. et al. 2009; DövényI, Z. and Kovács, Z. 2006; LeetmaA, K. and TAmmaru, T. 2007; StANILOv, K. and SýKORA, L. 2014). After the collapse of the communist regime the better off inhabitants of post-socialist cities discovered the green suburbs, just like the newly established enterprises that were searching for 'good location' in the core areas of the evolving capitalist economies. Economic restructuring and urban sprawl changed the previous equilibrium of jobs both within Hungary and the metropolitan region of Budapest.

The metropolitan area of Budapest is without doubt the main beneficiary of post-socialist transformation in Hungary. The city and its metropolitan zone has been the main target of foreign capital investment and technology transfer, the focus of the development of the most innovative branches of the economy within Hungary. Consequently, the weight of Budapest and its metropolitan region in the national employment and labour flows has significantly increased.

The rapid transformation of Budapest after 1989 the re-establishment of market mechanisms, the privatisation of housing, the liberalisation of the property market, and the growing re-integration of the city to the world economy affected not only the core city but also the metropolitan periphery. The previously rather homogeneous structure of the metropolitan periphery experienced significant changes in the course of the transformation. In the metropolitan region of Budapest new residential areas, large retail centres, logistics centres, industrial high-tech activities and office complexes appeared and mixed in certain clusters. After the political transition the advantages of location, which had been insignificant during the state-socialist period, once again became truly beneficial which resulted in growing disparities in the metropolitan periphery. Areas with high developmental dynamics emerged in places which provided a combination of optimal accessibility and low location costs.

Since 1990 the functional interplay, cooperation, interdependence as well as physical infrastructural linkages between Budapest and its metropolitan zone have been further intensified. Residential suburbanisation and the suburbanisation of business activities led to new flows of commuting within the metropolitan region. Generally, the share of the compact city in commuting flows within the metropolitan region decreased, whereas the role of the Functional Metropolitan Area (FMA) increased.

The flow of commuters is still concentrated on Budapest with its flourishing labour-market, however, its previous hierarchical connection with the inner part of the metropolitan zone (FMA) has been loosen. Local job centres in the FMA (Budaörs, Gödöllő, Vác, Veresegyház etc.) started to attract labour in 
great number from the core city and also from the neighbouring municipalities. The role of reciprocal connections increased not only between Budapest and its FMA, but also among centres of FMA, consequently, the spatial structure of the Budapest Metropolitan Region has become more polycentric since the early 1990s. In the light of the literature we can also say that the reallocation of urban functions took place in the wider metropolitan zone of Budapest among existing centres, which fits to the European version of post-suburbanisation concept rather than the US one. The phenomenon of 'leap frogging' has remained very limited.

Acknowledgements: This research was supported by the Hungarian Scientific Research Fund (OTKA) Grant Agreement no. K 105534, "Spatial Pattern of Post-socialist Urbanisation in Hungary".

\section{REFERENCES}

Albrechts, L. 2001. How to proceed from image and discourse to action: as applied to the Flemish Diamond. Urban Studies 38. (4): 733-745.

Anas, A., Arnott, R. and Small, K. 1998. Urban Spatial Structure. Journal of Economic Literature 36. (3): 1426-1464.

Axenov, K., BRADE, I. and BondARChuK, E. 2006. The transformation of urban space in post-Soviet Russia. London, Routledge, 196 p.

Bailey, N. and Turok, I. 2001. Central Scotland as a polycentric urban region: useful planning concept or chimera. Urban Studies 38. (4): 697-715.

Bontje, M. 2001. Dealing with deconcentration: population deconcentration and planning response in polynucleated urban regions in North-west Europe. Urban Studies 38. (4): 769-785.

Bontje, M. and Burdack, J. 2011. Post-suburbia in continental Europe. In International perspectives on suburbanization. A post-suburban world? Eds. Phelps, N. and Wu, F., Basingstoke, Palgrave Macmillan, 143-162.

Bontje, M. and Kepsu, K. 2013. Creative knowledge strategies for polycentric city-regions. In Place-making and Policies for Competitive Cities. Eds. Musterd, S. and Kovács, Z., Oxford, Wiley-Blackwell, 191-208.

Brade, I., Herfert, G. and Wiest, K. 2009. Recent trends and future prospects of sociospatial differentiation in urban regions of Central and Eastern Europe: A lull before the storm? Cities 26. (5): 233-244.

Brenner, N. and Theodore, N. 2002. Cities and the Geographies of "Actually Existing Neoliberalism". Antipode 34. (3): 349-379.

Burger, M. and Meijers, E. 2012. Form follows function? Linking morphological and functional polycentricity. Urban Studies 49. (5): 1127-1149.

Champion, A.G. 2001. A changing demographic regime and evolving polycentric urban regions: Consequences for the size, composition and distribution of city populations. Urban Studies 38. (4): 657-677.

CRILley, D. 1993. Megastructures and urban change: aesthetics, ideology and design. In The restless urban landscape. Ed. KNox, P.L., Englewood Cliffs, NJ, Prentice Hall, 131-164. 
Davoudi, S. 2003. Polycentricity in European spatial planning: from an analytical tool to a normative agenda. European Planning Studies 11. (8): 979-999.

De Goei, B., Burger, M., Van Oort, F. and Kitson, M. 2010. Functional polycentrism and urban network development in the Greater South East, United Kingdom: evidence from commuting patterns, 1981-2001. Regional Studies 44. (9): 1149-1170.

DövÉNYI, Z. and KovÁcs, Z. 2006. Budapest: Post-socialist metropolitan periphery between 'catching up' and individual development path. European Spatial Research and Policy 13. (2): 23-41.

Duranton, G. and Puga, D. 2004. Micro-foundations of urban agglomeration economies. In Handbook of Regional and Urban Economics, Volume 4. Eds. Henderson, V.J. and Thisse, J-F., Oxford, Elsevier, 2063-2117.

FAludi, A. 2004. The European Spatial Development Perspective and North-West Europe: application and the future. European Planning Studies 12. (3): 391-408.

FINKA, M. 2009. Sustainable territorial development and concepts of polycentricity in Slovak territorial development. Urban Research and Practice 2. (3): 332-343.

Fujita, M., Krugman, P. and Venables, A.J. 2000. The spatial economy - cities, regions and international trade. Cambridge, Massachusetts, MIT Press, $367 \mathrm{p}$.

Garreau, J. 1992. Edge city. Life on the new frontier. New York, Anchor Books, 548 p.

Gentile, M., Tammaru, T. and Van Kempen, R. 2012. Heteropolitanization: Social and spatial change in Central and Eastern European cities. Cities 29. (5): 291-299.

Hall, P. 1993. Forces shaping urban Europe. Urban Studies 30. (6): 883-898.

Hall, P. 2009. Polycentricity. In International Encyclopedia of Human Geography. Eds. Kitchin, R. and Thrift, N., Oxford, Elsevier, 260-264.

Hall, P. and Pain, K. 2006. From metropolis to polyopolis. In The Polycentric Metropolis. Learning from mega-city regions in Europe. Eds. HaLL, P. and Pain, K., Oxford, Earthscan, 3-16.

Harvey, D. 1978. The Urban Process Under Capitalism: A Framework for Analysis. International Journal of Urban and Regional Research 2. (1-4): 101-131.

KeIL, R. and Young, D. 2011. Post-suburbia and the city-region politics. In International perspectives of suburbanization. A post-suburban world? Eds. PhelPs, N.A. and Wu, F., Basingstoke, Palgrave Macmillan, 54-78.

Knox, P. L. 2008. Metroburbia, USA. New Brunswick, NJ, Rutgers University Press, 231 p.

Кок, Н. and Kovícs, Z. 1999. The process of suburbanization in the agglomeration of Budapest. Netherlands Journal of Housing and the Built Environment 14. (2): 119-141.

Kovács, Z. and Tosics, I. 2014. Urban Sprawl on the Danube: The Impacts of Suburbanization in Budapest. In Confronting Suburbanization: Urban Decentralization in Postsocialist Central and Eastern Europe. Eds. Stanilov, K. and Sýковa, L., Oxford, Wiley-Blackwell, 33-64.

Krugman P. 2000. Where in the world is the new economic geography. In The Oxford Handbook of Economic Geography. Eds. Clark, G.L., Fedman, M.P. and Gertler, M.S., Oxford, Oxford University Press, 49-60.

LeetmaA, K. and Tammaru, T. 2007. Suburbanization in countries in transition: destination of suburbanizers in the Tallinn Metropolitan Area. Geografiska Annaler, Series B: Human Geography 89. (2): 127-146.

Lehrer, U.A. 1994. The Image of the Periphery: The Architecture of FlexSpace. Environment and Planning D: Society and Space 12. (2): 187-205.

Logan, J.R. and Swanstrom, T. 2005. Urban Restructuring: A Critical View. In Cities and society. Ed. Kleniewski, N., Oxford, Blackwell, 28-42.

Maier, K. 2009. Polycentric development in the spatial development policy of the Czech Republic. Urban Research and Practice 2. (3): 319-331. 
Malmberg, A. 2009. Agglomeration. In International Encyclopedia of Human Geography, Eds. Kitchin, R. and Thrift, N., Oxford, Elsevier, 48-53.

OuREDNIČEK, M. 2007. Differential suburban development in the Prague urban region. Geografiska Annaler, Series B: Human Geography 89. (2): 111-126.

Peet, R. and Hartwick, E. 2009. Theories of Development. Contentions, Arguments, Alternatives. London, Guilford Press, 324 p.

PhelPs, N. and Wu, F. 2011. Introduction. In International perspectives of suburbanization. A postsuburban world? Eds. Phelps, N.A. and Wu, F., Basingstoke, Palgrave Macmillan, 1-12.

Pichler-Milanović, N. 2014. Confronting Suburbanization in Ljubljana: From “Urbanization of the Countryside" to Urban Sprawl. In Confronting Suburbanization: Urban Decentralization in Post-socialist Central and Eastern Europe. Eds. Stanilov, K. and SÝKora, L., Oxford, Wiley-Blackwell, 65-96.

RADVÁNSZKY, Á. 2009. Old wine in a new bottle? The Hungarian approach to polycentric territorial development. Urban Research and Practice 2. (3): 308-318.

Rosenthal, S.S. and StRAnge, W. 2004. Evidence on the nature and sources of agglomeration economies. In Handbook of Regional and Urban Economics, Volume 4. Eds. Henderson, V. J. and Thisse, J-F., Oxford, Elsevier, 2119-2171.

SAssen, S. 2001. Global cities and global city-regions. In Global city-regions. Ed. ScotT, A.J., Oxford, Oxford University Press, 78-95.

Scott, A.J., Agnew, J., SojA, E. and Storper, M. 2001. Global city-regions. In Global city-regions. Ed. Sсотт, A.J., Oxford, Oxford University Press, 11-30.

Sмiтh, N. 1982. Gentrification and Uneven Development. Economic Geography 58. (2): 139-155.

Soja, E.W. 1996. Thirdspace: Journeys to Los Angeles and other real-and-imagined places. Oxford, Blackwell, $348 \mathrm{p}$.

StANILOv, K. and SÝKORA, L. eds. 2014. Confronting suburbanization: urban decentralization in postsocialist Central and Eastern Europe. Oxford, Wiley-Blackwell, 333 p.

SýKora, L. 2009. Post-Socialist Cities. In International Encyclpedia of Human Geography. Eds. Kiтchin, R. and Thrift, N., Oxford, Elsevier, 387-395.

Vandermotten, C., Halbert, L., Roelandts, M. and Cornut, P. 2008. European planning and the polycentric consensus: wishful thinking? Regional Studies 42. (8): 1205-1217.

Volgmann, K. 2012. Neue Kerne in metropolitanen Räume - Polyzentrische Strukturen und Funktionen in Metropolraum Rhein-Ruhr. In Polyzentrale Stadtregionen - die Region als planerische Handlungsraum. Hrsg. Growe, A., Heider, K., Lamker, C., Passlick, S. and Terfrüchte, T., Hannnover, Akademie für Raumforschung und Landesplanung, Forschungsbericht 3 . 


\title{
Ukraine in Maps
}

\section{Edited by: Kocsis, K., Rudenko, L. and Schweitzer, F.}

\author{
Institute of Geography National Academy of Sciences of Ukraine \\ Geographical Research Institute Hungarian Academy of Sciences. \\ Kyiv-Budapest, 2008, 148 p.
}

Since the disintegration of the USSR, the Western world has shown an ever-growing interest in Ukraine, its people and its economy. As the second-largest country in Europe, Ukraine has a strategic geographical position at the crossroads between Europe and Asia. It is a key country for the transit of energy resources from Russia and Central Asia to the European Union, which is one reason why Ukraine has become a priority partner in the neighbourhood policy of the EU. Ukraine has pursued a path towards the democratic consolidation of statehood, which encompasses vigorous economic changes, the development of institutions and integration into European and global political and economic structures. In a complex and controversial world, Ukraine is building collaboration with other countries upon the principles of mutual understanding and trust, and is establishing initiatives aimed at the creation of a system that bestows international security.

This recognition has prompted the Institute of Geography of the National Academy of Sciences of Ukraine (Kyiv) and the Geographical Research Institute of the Hungarian Academy of Sciences (Budapest) to initiate cooperation, and the volume entitled "Ukraine in Maps" is the outcome of their joint effort. The intention of this publication is to make available the results of research conducted by Ukrainian and Hungarian geographers, to the English-speaking public. This atlas follows in the footsteps of previous publications from the Geographical Research Institute of the Hungarian Academy of Sciences.

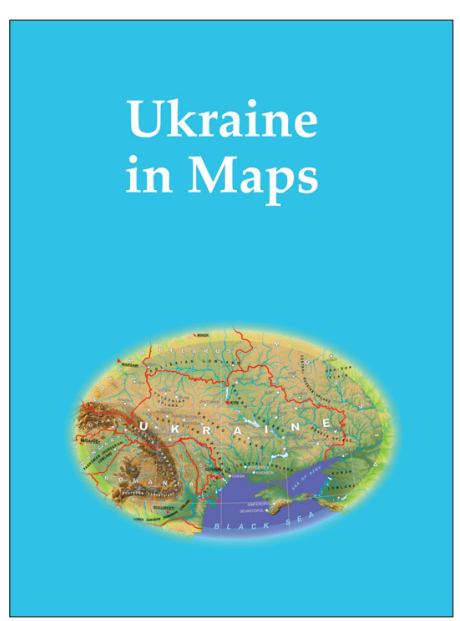
Similar to the work entitled South Eastern Europe in Maps (2005, 2007), it includes 64 maps, dozens of figures and tables accompanied by an explanatory text, written in a popular, scientific manner. The book is an attempt to outline the geographical setting and geopolitical context of Ukraine, as well as its history, natural environment, population, settlements and economy. The authors greatly hope that this joint venture will bring Ukraine closer to the reader and make this neighbouring country to the European Union more familiar, and consequently, more appealing.

Price: EUR 35.00

Order: Geographical Institute RCAES HAS Library

H-1112 Budapest, Budaörsi út 45.

E-mail: magyar.arpad@csfk.mta.hu 